\title{
Crew Exploration Vehicle Potable Water System Verification Description
}

\author{
George C. Tuan ${ }^{1}$ and Laurie J. Peterson ${ }^{2}$, \\ NASA Johnson Space Center, Houston, Texas, 77058 \\ Leticia M. Vega ${ }^{3}$ \\ Jacobs Engineering, Houston, Texas 77058
}

\begin{abstract}
A stored water system on the crew exploration vehicle (CEV) will supply the crew with potable water for: drinking and food rehydration, hygiene, medical needs, sublimation, and various contingency situations. The current baseline biocide for the stored water system is ionic silver, similar in composition to the biocide used to maintain the quality of the water, transferred from the orbiter to the International Space Station, stored in contingency water containers. In the CEV water system, a depletion of the ionic silver biocide is expected due to ionic silver-plating onto the surfaces of materials within the CEV water system, thus negating its effectiveness as a biocide. Because this may be the first time NASA is considering a stored water system for long-term missions that do not maintain a residual biocide, a team of experts in materials compatibility, biofilms and point-of-use filters, surface treatment and coatings, and biocides has been created to pinpoint concerns and perform the testing that will help alleviate concerns related to the CEV water system.
\end{abstract}

\section{Introduction}

$\mathrm{T}$ HIS paper is a follow-on paper to a previous ICES paper. ${ }^{1}$ Significant detail on the crew exploration vehicle (CEV) Potable Water System (PWS) can be found in that paper. The main purpose of this paper is to document the verification plan based on results of the development testing that has been performed as well as to provide an update to the PWS.

\section{Potable Water System Description}

Unlike Apollo and shuttle, CEV does not use fuel cell technology for its power generation; as a result, no constant source of water is produced for use by the vehicle or the crew. Owing to this lack of water generation by the power system, CEV must carry all required water for the mission from the beginning to the end of the mission. This water must be loaded and stored on the vehicle for duration of the mission, which is a considerable amount of time when the 6-month quiescent phase is taken into consideration. If the actual loading to mission launch time is taken into account, storage time could be even longer.

The CEV water storage tanks consist of five metal bellows tanks in the service module (SM), which are the primary water tanks for potable use (i.e., drinking/food rehydration, hygiene, and suited operations). Volume and mass are limited in the crew module (CM), so it was decided that all water required for the entire mission be placed in the same SM water tanks. As a result, the same water tanks also provide water to the sublimators as a secondary heat-rejection device for use when the radiator is unable to fully reject all generated waste heat, and recharge water for the liquid cooling garment (LCG) loop. The crew accesses the potable water through the potable water dispenser (PWD), which provides a dispense port from which the crew can fill drink and food bags, and also a variety of other water bags, such as emergency eyewash and a Waste Management System (WMS) flush bag that is used to flush the WMS before the long-duration quiescent period. Inconel ${ }^{\circledR}$ bellows tanks have been chosen as the baseline design for

${ }^{1}$ Orion ECLS Subsystem Manager, Crew and Thermal System Division, NASA - JSC/EC6.

${ }^{2}$ Orion ECLS Subsystem Manager, Crew and Thermal System Division, NASA - JSC/EC6.

${ }^{3}$ Scientist, Crew and Thermal System Division, 2224 Bay Area Blvd, Houston, TX 77058, AIAA Member. 
the water tank due to the extensive experience that exist. The tanks are grouped together to allow generally consistent draining from all tanks and increase the robustness of the system should one tank become unavailable to the crew through either a tank and/or a valve failure

\section{Potable Water System Development Testing}

The baselined assumption for the CEV PWS is that it will have an initial biocide addition of ionic silver fluoride (AgF) to maintain water quality within microbial limits. The Human-Systems Integration Requirements (HSIR) document, $\mathrm{CxP} 70024$, defines the maximum limit for silver in PWSs as $0.4 \mathrm{mg} / \mathrm{L}$ at the point of consumption and maximum microbial contamination as less than 50 colony-forming units (CFUs) per $\mathrm{mL}$ also at the point of consumption. Silver is convenient to use as a biocide because, at low levels, it does not need to be removed before crew consumption; this is unlike iodine, which has to be removed from the water in shuttle prior to consumption. With the silver biocide two questions are raised, however. The first is the compatibility of silver with in-line wetted materials, and the second is to confirm biocide efficacy throughout the entire mission duration, as silver levels tends to decrease with time.

Because of the long-duration storage of the potable water in the PWS tanks, long-term water quality becomes a concern. Not only are there long-term physiochemical concerns, e.g., corrosion and material compatibility, there is also a microbial growth concern. As a result, a development plan was put into place to address these concerns and develop test plans to address risks. The plan focused on three specific areas: The first area is material compatibility testing. Interaction with the water and the wetted surfaces within the PWS can leads to leaching of materials that would cause long-term physiochemical issue with the water system. The second are is microbial growth control testing. Due to the long-term water storage with a potential of no active biocide, there was a major concern that the water would develop microbes that would put crew member health at risk. This led to the third development area of the point-of-use (POU) filter. The POU filter is a $0.1-\mu$ filter that has the ability to filter out microbes that may develop in the PWS.

\section{A. Material Compatibility Testing}

The three baseline wetted materials for the PWS are as follows Inconel ${ }^{\circledR} 718$ (bellows tank), Ti3Al2.5V (tubing), and E-BRITE ${ }^{\circledR}$ (wetted valve surfaces). These materials have historical uses on the International Space Station (ISS) PWS, so there is some long-term material compatibility data with these materials. One area of concern seen on the ISS tanks, also made of Inconel ${ }^{\circledR} 718$, is nickel leaching. On ISS, this increase in nickel can be traced to a lower water $\mathrm{pH}$ level of 5.0 resulting from the iodine biocide used on ISS. However, there was also concern that the silver biocide potable water, which can have a nominal $\mathrm{pH}$ as low as 5.5 , may also cause nickel leaching.

A long-term Inconel ${ }^{\circledR} 718$ bellows tank testing was performed at Hamilton Sundstrand's (HS's) Advanced Engineering Laboratory. They started with deionized (DI) water, exposed it to atmospheric carbon dioxide $\left(\mathrm{CO}_{2}\right)$ for about $2 \mathrm{hrs}$, added $0.4 \mathrm{ppm}$ silver as $\mathrm{AgF}$, and loaded it into a clean, heat-treated Inconel ${ }^{\circledR} 718$ bellows tank. The loaded water $\mathrm{pH}$ was around 5.6, which is within the water specification. After 14 months, the $\mathrm{pH}$ of the water was around 6.5 and the nickel was at $<0.1 \mathrm{ppm}$ [parts per million] throughout. With this result, it was shown that long-term leaching of nickel is not a concern with an Inconel ${ }^{\circledR} 718$ bellows tank loaded with silver biocide.

The other concern is the length of time that silver will stay in the water before plating on wetted metal surfaces through the system. This is a concern as the potable water is stored in Inconel ${ }^{\mathbb{Q}}$ bellows tank instead of polymer bladders used in contingency water containers on Shuttle and ISS. With no special treatment, the expected dwell time of silver in solution is less then 1 month inside the Inconel ${ }^{\circledR}$ tanks. The silver reacts with the Inconel ${ }^{\circledR}$ in the following chemical reaction. Oxidization of nickel leads to a reduction of ionic silver. The ionic silver reduces to metallic silver before it is deposited to silicon/niobium $(\mathrm{Si} / \mathrm{Nb})$-rich areas of the Inconel ${ }^{\circledR} 718$ that serve as cathodes (most noble areas of the surface). Nickel converts to nickel oxide $\left(\mathrm{Ni}_{2} \mathrm{O}\right)$, nickel hydroxide $\left(\mathrm{Ni}(\mathrm{OH})_{2}\right)$, and /or nickel carbonate $\left(\mathrm{NiCO}_{3}\right)$ and remains bound to the surface, as in the following:

$$
\begin{gathered}
\mathrm{Ni}(\mathrm{s}) \rightarrow \mathrm{Ni}_{2}+(\mathrm{aq})+2 \mathrm{e}- \\
2 \mathrm{Ag}+(\mathrm{aq})+2 \mathrm{e}-\rightarrow 2 \mathrm{Ag}(\mathrm{s})
\end{gathered}
$$

Surface treatment methods were explored to extend silver duration within the potable water tanks. A method of high-temperature oxidation of Inconel ${ }^{\mathbb{B}} 718$ tanks combined with a high concentration of AgF treatment has shown to significantly increase the duration of dissolved ionic silver in potable water. Even after 432 days testing, the silver level in testing was shown to be at $0.35 \mathrm{ppm}$, with the silver level starting at $0.4 \mathrm{ppm}$ at the beginning of test. 
Unfortunately, this surface treatment test does not show as dramatic a life increase for silver and the titanium tubing. However, because the majority of the water is stored in the tanks and the expected flow-through time in the tubing is relatively short, this is not as major a concern.

\section{B. Microbial Control Testing}

The overall goal of the ionic silver compatibility and microbial control development test is to successfully process the bellows tank and supporting hardware and subject it to long-term storage and sampling to ensure microbial water quality parameters are met throughout the planned duration of the CEV/lunar missions (i.e., 300-day duration). The planned processing procedure, such as any cleaning procedure, flush time and temperature, and sterilization process required to control microbes, will be modeled after the processing scheme used for processing the ISS water processor assembly (WPA) flight hardware. The testing system consisted a bellows tank of similar material to the CEV potable water tanks (Inconel ${ }^{\circledR} 718$ ) as well as the accompanying hardware required to facilitate long-term water storage and testing.

The bellows tank was first put through a series of DI water flushes to remove residual organic material. No special surface treatment was applied to the tank, however. Each DI water flush of the bellows tank was analyzed for total organic carbon (TOC) following completion of the respective flush. In all cases, TOC reported from the bellows tank was less than $0.1 \mathrm{mg} / \mathrm{L}$-TOC. The associated fittings, plumbing, and valves were precision-cleaned and flushed with DI water followed by hot gaseous nitrogen flush to remove residual cleaning agents. The tank, plumbing fixtures, and valves were then placed in an oven and heat-treated in accordance with HS specifications for heat sterilization, which was used on the ISS WPA flight hardware. The tank and plumbing were capped and filled with sterile DI water, following which the heating step samples were taken for TOC analysis $(<0.8 \mathrm{mg} / \mathrm{L}-\mathrm{TOC})$. After acceptance of all processing procedures, the tank and plumbing fixtures were assembled together and filled with DI water containing $0.40 \mathrm{mg} / \mathrm{L}-\mathrm{Ag}$ as $\mathrm{AgF}$. DI water was charged into the tank through a $0.1-\mu \mathrm{m}$ filter, effectively coldsterilizing the fluid on charging. Samples were obtained at this point from the tank and also from a POU filter at the plumbing outlet and were analyzed for TOC, silver, and microbial populations. Results indicated that no microbial populations were present in the water, and also that the TOC was $<0.5 \mathrm{mg} / \mathrm{L}$ which meets the HSIR requirments.

Water quality samples were taken on a monthly basis for the mentioned parameters for a total duration of 10 months. After 10 months, testing showed a low TOC levels and no detectable CFUs in the bellow tank or the plumbing line. Testing was continued, with reduced sampling, to over 17 months. At the end of testing, there were still no detectable CFUs in either the bellow tank or the plumbing line, figure 1.

\begin{tabular}{|c|c|c|}
\hline Day & Bellows Tank & POU/Plumbing \\
\hline & TOC (ppm) & TOC (ppm) \\
\hline 0 & 0.24 & 4.3 \\
\hline 5 & 0.3 & 1 \\
\hline 26 & 0.3 & 1.54 \\
\hline 61 & 0.25 & 2 \\
\hline 84 & 0.2 & 2.2 \\
\hline 113 & 0.2 & 1.4 \\
\hline 141 & 0.25 & 1.36 \\
\hline 178 & 0.17 & 1.3 \\
\hline 212 & 0.2 & 1.3 \\
\hline 254 & 0.33 & 1.26 \\
\hline 282 & 0.27 & 1.05 \\
\hline 316 & 0.19 & 0.97 \\
\hline 352 & 0.37 & 0.9 \\
\hline 392 & 0.24 & 0.53 \\
\hline 432 & 0.23 & 0.52 \\
\hline 524 & 0.24 & 0.33 \\
\hline
\end{tabular}

\begin{tabular}{|c|c|c|}
\hline Day & Bellows Tank & POU/Plumbing \\
\hline & CFU/mL & CFU/mL \\
\hline 0 & 0 & 0 \\
\hline 26 & 0 & 0 \\
\hline $61^{*}$ & $0(250)$ & $0(1727.5)$ \\
\hline 84 & 1 & 1 \\
\hline 113 & 0 & 0 \\
\hline 141 & 1 & 0 \\
\hline 178 & 0 & 0 \\
\hline 212 & 0 & 0 \\
\hline 254 & 0 & 0 \\
\hline 282 & 0 & 0 \\
\hline 316 & 0 & 0 \\
\hline 352 & 0 & 0 \\
\hline 392 & 0 & 0 \\
\hline 432 & 0 & 1 \\
\hline 526 & 0 & 0 \\
\hline
\end{tabular}

Figure 1. Bellows tank testing result.

3

American Institute of Aeronautics and Astronautics 


\section{Point-of-use Filter Testing}

Two separate sets of POU filter testing were performed to evaluate the long-term effectiveness of the selected POU, as well as a challenge test to determine whether microbial breakthrough is possible. The first set of testing test was performed to test the efficiency of the filter over a length of time with a standard set of challenge microorganisms and also to measure the filtration efficiency in a simulated PWS system over a duration of a lunar mission. The second set of testing is to determine if the POU filter can suffer breakthrough if exposed to the worst case microbial growth in a PWS without any biocide for the duration of a lunar mission.

\section{POU Filter efficiency testing}

The objective of the filter efficiency testing, done at NASA-Kennedy Space Center, was to verify the microbial control effectiveness of the selected POU filter. A series of evaluations was performed, including standard methods testing for filter elements, space-isolated bacteria challenges, effects of prolonged inoculation of filter elements, and a system simulation test. With these tests, the efficacy of filters to maintain water quality within microbial limits was verified, which alleviated concerns about water quality from the CEV PWS.

The POU filter selected for testing was a Mini Kleenpak ${ }^{\mathrm{TM}}$ capsule with Fluorodyne hydrophilic PVDF 0.1 micron filter media (Pall part number (P/N) KA02DJLP2S). Testing can be characterized into two specific tasks 1) modified American Society for Testing and Materials (ASTM) filter evaluation, and 2) system simulation filter testing.

Modified ASTM testing borrows from ASTM F838-05, which is a specific standard for evaluation of $0.2-\mu \mathrm{m}$ filters. Although there is no equivalent ASTM method for $0.1-\mu \mathrm{m}$ filters, the industry-accepted challenge organism is Acholeplasma laidlawii (ATCC 23206), tested at a pressure of $7 \mathrm{psi}$ [pounds per square inch]. These spherical organisms vary in size from less than $0.1 \mu \mathrm{m}$ to approximately $0.4 \mu \mathrm{m}$ in diameter. In addition to the challenge of testing with the industry-accepted organism, the filters was also be challenged with Brevundimonas diminuta (ATCC 19146), the recommended $0.2-\mu \mathrm{m}$ challenge organism outlined in ASTM F838-05. ${ }^{2}$ Finally, a challenge test that uses spacecraft-isolated microorganisms (i.e., Burkholderia cepacia, Cupriavidus metallidurans, Methylobacterium fujisawaense, Pseudomonas aeruginosa, Sphingomonas paucimobilis) was also employed. Ten filters were challenged with each of the three groups (a total of 30 filters). The filters were stored in separate, sealed polypropylene bags, and duplicate filters were re-challenged after $30,60,120$, and 230 days. Filtration efficiency was estimated by measuring cell density (CFUs) and direct cell count in the filtrate. Figure 2 shows the testing results, which showed no breakthrough after 240 days.

\begin{tabular}{|c|c|c|c|c|c|c|c|c|c|c|c|c|}
\hline & \multicolumn{4}{|c|}{ Brevundimonas diminuta } & \multicolumn{4}{|c|}{ Acholeplasma laidlawii } & \multicolumn{4}{|c|}{ Isolated Spacecraft Microorganisms } \\
\hline & \multicolumn{2}{|c|}{$\begin{array}{c}\text { Total Counts } \\
(\mathrm{AO})\left(\text { cells } \mathrm{mL}^{-1}\right)\end{array}$} & \multicolumn{2}{|c|}{ 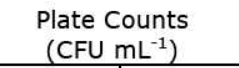 } & \multicolumn{2}{|c|}{$\begin{array}{l}\text { Total Counts } \\
(\mathrm{AO})\left(\text { cells } \mathrm{mL}^{-1}\right)\end{array}$} & \multicolumn{2}{|c|}{$\begin{array}{l}\text { Plate Counts } \\
\left(\text { CFU mL } \mathrm{mL}^{-1}\right)\end{array}$} & \multicolumn{2}{|c|}{$\begin{array}{c}\text { Total Counts } \\
(\mathrm{AO})\left(\text { cells } \mathrm{mL}^{-1}\right)\end{array}$} & \multicolumn{2}{|c|}{$\begin{array}{l}\text { Plate Counts } \\
\left(\text { CFU mL } \mathrm{mL}^{-1}\right)\end{array}$} \\
\hline Day & Influent & Filtrate & Influent & Filtrate & Influent & Filtrate & Influent & Filtrate & Influent & Filtrate & Influent & Filtrate \\
\hline $\mathbf{0}$ & $5.1 \times 10^{8}$ & N/A & $8.1 \times 10^{7}$ & 0 & $6.6 \times 10^{8}$ & 0 & $\begin{array}{c}4.17 \times \\
10^{7} \\
\end{array}$ & 0 & $5.5 \times 10^{8}$ & 0 & $2.7 \times 10^{7}$ & 0 \\
\hline 30 & $6.6 \times 10^{8}$ & 0 & $5.3 \times 10^{7}$ & 0 & $8.1 \times 10^{8}$ & 0 & $2.2 \times 10^{7}$ & 0 & $9.2 \times 10^{8}$ & 0 & $\mathrm{~N} / \mathrm{A}$ & 0 \\
\hline 60 & $5.0 \times 10^{8}$ & $\begin{array}{l}<1 \text { cell } \\
\text { field }^{-1}\end{array}$ & $1.9 \times 10^{7}$ & 0 & $4.0 \times 10^{9}$ & 0 & $2.5 \times 10^{7}$ & 0 & $9.4 \times 10^{8}$ & 0 & $7.2 \times 10^{7}$ & 0 \\
\hline 120 & $1.6 \times 10^{9}$ & $\begin{array}{l}<1 \text { cell } \\
\text { field }^{-1}\end{array}$ & $1.1 \times 10^{9}$ & 0 & $4.1 \times 10^{9}$ & $\begin{array}{l}<1 \text { cell } \\
\text { field }^{-1}\end{array}$ & $8.3 \times 10^{7}$ & 0 & $1.3 \times 10^{9}$ & $\begin{array}{l}<1 \text { cell } \\
\text { field }^{-1}\end{array}$ & $7.1 \times 10^{7}$ & 0 \\
\hline 240 & $1.3 \times 10^{9}$ & 0 & $1.5 \times 10^{8}$ & 0 & $6.9 \times 10^{8}$ & 0 & $3.4 \times 10^{7}$ & 0 & $1.2 \times 10^{9}$ & 0 & $8.7 \times 10^{8}$ & 0 \\
\hline
\end{tabular}

Figure 2. POU challenge testing result. 
Filter system efficiency simulation testing involves a test setup designed to mimic a lunar mission timeline to determine the effects of long-term use on the POU filters. Potable water in this test was inoculated with a background concentration of challenge bacteria at a concentration of approximately $10^{2} \mathrm{CFU} / \mathrm{mL}$ and charged with water containing a $0.4 \mathrm{ppm}$ silver concentration. The POU filters used in the test was plumbed into a common manifold device; all contain a simulated dispensing needle that will be exposed to the laboratory environment during the duration of the testing. This simulated the possible worst-case scenarios, with the potable water being charged into a "dirty" system. Water in the tanks will sit for approximately 8 weeks to simulate the time between vehicle processing and launch and crew occupancy. To simulate CEV water use, the filters will be used under similar mission requirements with respect to daily use, flow rate, and pressure. The primary filters will be used daily for 7 days to simulate lunar transit scenarios, while all other filters will be exposed to potable water on day 1 , but then will be isolated until their respective re-test date approximately $30,60,120$ and 230 days from the start of the test. The filter elements will be tested on their respective dates in the system simulation test, after which they will also be evaluated under the modified ASTM method. Destructive sampling of the filter elements will only be warranted in case of failure under the ASTM method with respect to exceeding specified microbial counts (i.e., $50 \mathrm{CFU} / \mathrm{mL}$ ).

The silver concentration showed a steady decline, as expected. After 30 days, it was halved to the 0.21 to $0.27 \mathrm{ppm}$ range and to $0.12 \mathrm{ppm}$ at day 60 . The overall bacterial level in the tank increased as well.

Testing results, figure 3, showed microbiological in the sample taken after the POU filter starting from the first month sample. But after further analysis, it was suspected that the microbial contamination was a result of the dispensing needle left in the room and not microbial breakthrough of the filter. This was suspected because the types of bacteria sampled were not the same types that were loaded initially in the water. A sample at day 60 was taken without a needle and showed no microbial in the sample. This was further shown to be the case when the dispensing needles were replaced with a sterile one prior to sampling and no microbial colonies was found.

\begin{tabular}{|l|c|c|c|c|}
\hline \multirow{2}{*}{ Day } & \multicolumn{2}{|c|}{$\begin{array}{c}\text { Total Counts (AO) } \\
\left(\text { cells } \mathrm{mL}^{-1}\right)\end{array}$} & \multicolumn{2}{c|}{$\begin{array}{r}\text { Plate Counts } \\
\left(\mathrm{CFU} \mathrm{mL}{ }^{-1}\right)\end{array}$} \\
\cline { 2 - 5 } & Tank & Filtrate & Tank & Filtrate \\
\hline 0 & $2.16 \times 10^{4}$ & $5.81 \times 10^{3}$ & 21 & 0 \\
\hline 7 & $1.72 \times 10^{4}$ & 0 & $1.08 \times 10^{4}$ & 0 \\
\hline 30 & $4.41 \times 10^{4}$ & $5.02 \times 10^{3}$ & 10 & 57 \\
\hline 60 & $1.95 \times 10^{4}$ & $1.95 \times 10^{3}$ & 110 & 50 \\
\hline $60^{*}$ w/o needle & & $<1$ cell field ${ }^{-1}$ & & 0 \\
\hline 120 & $5.56 \times 10^{4}$ & $8.80 \times 10^{3}$ & $2.6 \times 10^{3}$ & 54 \\
\hline 120 with newneedle & & $<1$ cell field ${ }^{-1}$ & & 0 \\
\hline 185 & $7.83 \times 10^{4}$ & 0 & $4.0 \times 10^{3}$ & 50 \\
\hline 185 w/o needle & & 0 & & 0 \\
\hline 237 & $1.53 \times 10^{5}$ & $1.65 \times 10^{5}$ & $2.61 \times 10^{4}$ & 0 \\
\hline 237 (w/o needle) & & 0 & & 0 \\
\hline 241 & $1.66 \times 10^{5}$ & 0 & $2.57 \times 10^{4}$ & 30 \\
\hline 241 (w/o needle) & & 0 & & 0 \\
\hline
\end{tabular}

Figure 3. POU system simulation testing result.

\section{POU breakthough testing}

Overall objectives of the CEV POU filter testing at NASA-Johnson Space Center were to provide supplemental data on the quality of water to be loaded into the potable water tanks and to determine the lifetime of a $0.1-\mu \mathrm{m}$ filter if it is the sole microbial barrier in a PWS. This is the second major test in the Point-of-use Physical Barrier Systems Project, hereafter called "Phase II." 
Phase II was made up of two sub-tests. The first part, Part I, determined what the worst-case bacterial concentration CEV potable water tanks would be if no biocide was present. Stainless-steel containers filled with 0.1$\mu \mathrm{m}$ filtered DI water and 0 to $3 \mathrm{mg} / \mathrm{L}$ TOC, encompassing the minimum and maximum TOC concentration allowed per HSIR requirements, were placed in a temperature-controlled chamber mimicking the diurnal temperature variation at Cape Canaveral, Fla., for a period of 45 days. There were two controls for the test; the first was a container filled with DI water and approximately $50 \mathrm{CFU} / \mathrm{mL}$ Burkholderia cepacia, a bacterial species isolated from shuttle potable water supplies. The second container was filled with DI water, $50 \mathrm{CFU} / \mathrm{mL} \mathrm{B}$. cepacia, and 3 $\mathrm{mg} / \mathrm{L}$ TOC. The controls, along with the samples, represent a nominal and worst-case scenario in terms of TOC and bacterial concentrations. Samples were collected at test days $0,1,2,23,32$, and 45 for TOC and heterotrophic plate counts analyses. Figure 4 illustrates the microbial concentrations during Part I.

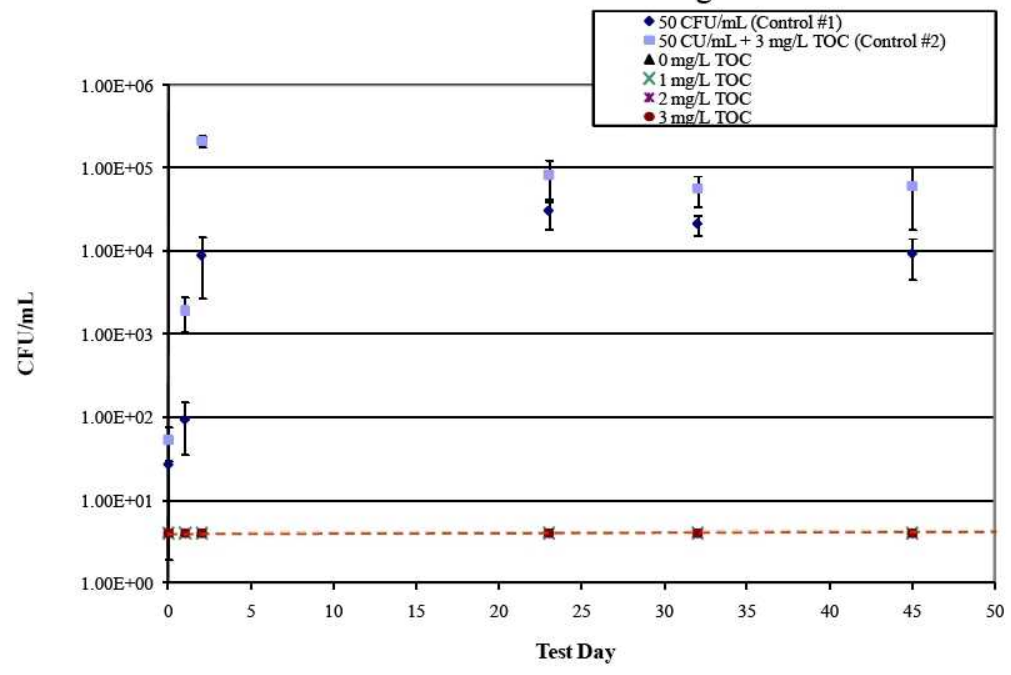

Figure 4. Average microbial concentrations during Part1.

The dashed red line represents the minimum measurable microbial concentration during the test as there were no detected colonies in the $250 \mu \mathrm{l}$ sample. Since the water will be filtered and the TOC concentration will be low, it was expected there would be little to no microbial growth in the test containers. The control containers describe a different story. The microbial concentrations in both controls on the order of 4-5 logs and reach these concentrations within 3 days. In addition to the high bacterial concentrations, the second control set produced a light biofilm on the inner surface of the test containers and a noticeable floc in the fluid by test day 32 (Figure 5).

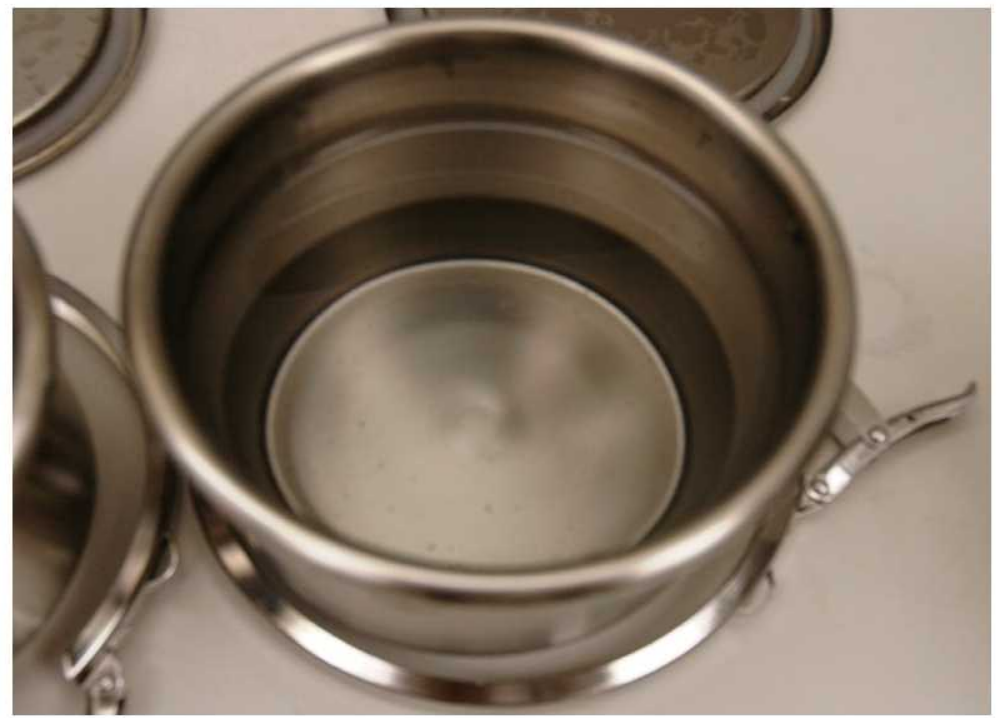

Figure 5. Formation of biofilm and floc (opaque spots) in test containers. 
This is not an unusual phenomenon; the literature describes biofilm formation at TOC concentrations above 0.5 $\mathrm{mg} / \mathrm{L}$. Water with less than $0.5 \mathrm{mg} / \mathrm{L}$ organic carbon is considered "biologically stable;" where some microbial processes are inhibited and microbial growth can be reduced ${ }^{3}$. In water with a TOC concentration above $0.5 \mathrm{mg} / \mathrm{L}$, as much as $50 \%$ of the organic carbon can be converted into biomass. This difference between control sets can be seen in Figure 6.

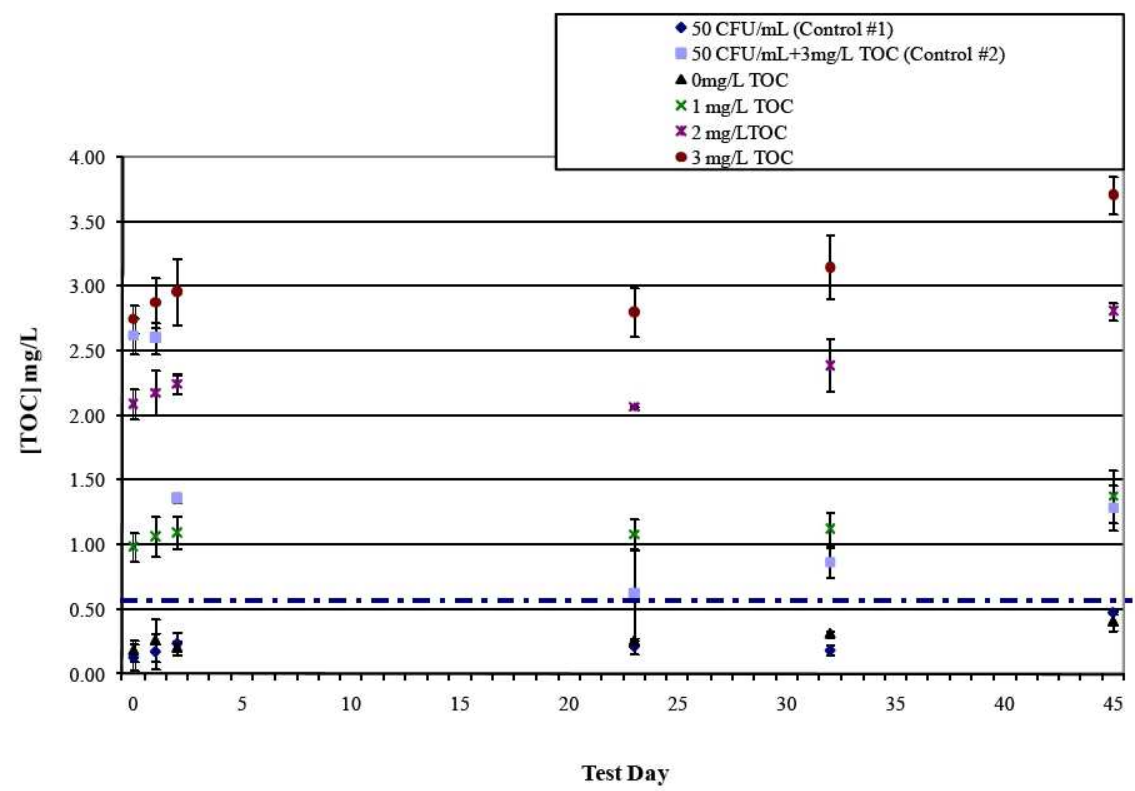

Figure 6. TOC concentrations during Part I.

The TOC concentration of the first control set and the test containers remained constant throughout Part I; however, the second control set displayed a significant drop in TOC concentration during Part I, particularly during the first 3 days. A total suspended solids analysis of the second control set was completed when Part I ended to determine how much biomass was produced from the added TOC. The total suspended solids averaged $0.85 \mathrm{mg} / \mathrm{L}$, approximately a 28-percent conversion of the TOC to biomass.

Because of the noticeable biomass production in the second control set during Part I, a small side experiment was performed with the sterile test containers containing $1-3 \mathrm{mg} / \mathrm{L}$ TOC. As in the control sets, the test containers were spiked with approximately $50 \mathrm{CFU} / \mathrm{ml} \mathrm{B}$. cepacia and returned to the temperature chamber for 46 days. The containers were checked occasionally to determine if biofilm formation occurred in the containers with the lower concentrations of TOC and on what day biofilm formation would be noticeable. Samples were collected from each container at the end of the test for an HPC (Figure 7).

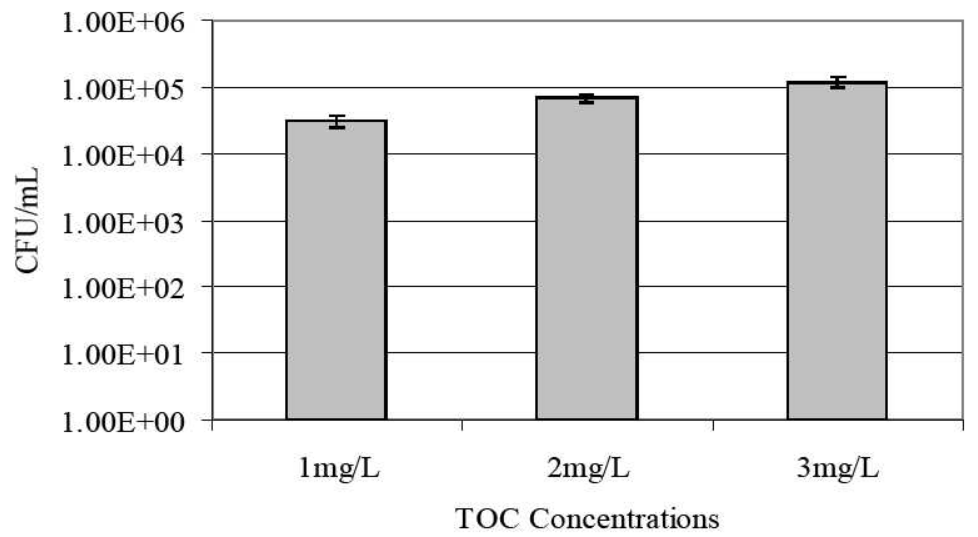

Figure 7. Bacterial concentrations in the presence of TOC. 
A slight difference exists between bacterial concentration in the presence of different concentrations of TOC, but all are at least 3 orders of magnitude above the $50 \mathrm{CFU} / \mathrm{ml}$ limit. Biofilm and floc formation was noticed in only one test container at 2 and $3 \mathrm{mg} / \mathrm{L} \mathrm{TOC}$ at test days 16 and 46, respectively.

The second part of Phase II, Part II, evaluated whether a $0.1-\mu \mathrm{m}$ filter (Pall Kleenpak ${ }^{\mathrm{TM}}$ KA02DJLP2S) was able to act as a stand-alone microbial barrier in the event of a worst-case scenario. Part II was a challenge test based on ASTM F838-05, the method described in the previous section. A feed tank was filled with $20 \mathrm{~L}$ of filtered DI water and spiked with a 5-log microbial challenge based on the results from Part I. The bacterial species that was used during this portion of the test was Brevundimonas diminuta due to its small size and use as a challenge organism for $0.2-\mu \mathrm{m}$ filters. Spiked water flowed through the filter at a rate of $500 \mathrm{~mL} / \mathrm{min}$. Samples for microbial analysis were collected from sample ports upstream and downstream of the filter during each 20 -L run. Once the volume was exhausted, the feed tank was refilled and the test repeated until the pressure drop reached 24 psid [pounds per square inch, differential] from inlet to outlet, the maximum allowed pressure drop at $176^{\circ} \mathrm{F}$ where filter replacement is recommended by Pall, or until $254 \mathrm{~L}$ of water, the volume of a 5-tank configuration in CEV, passed through the filter.

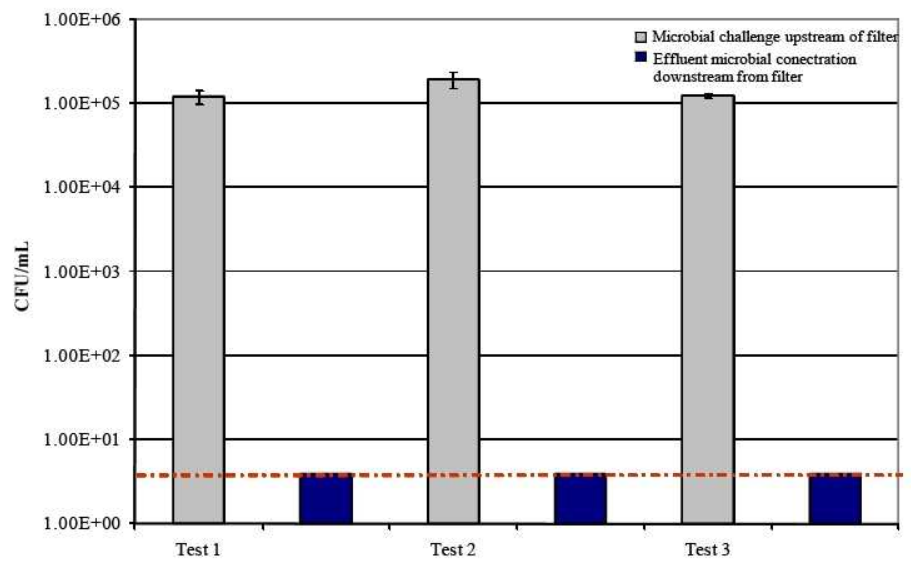

Figure 8. Results of Part II challenge study

The flowrate of all three tests averaged between 473 and $492 \mathrm{~mL} / \mathrm{min}$, just below the $500 \mathrm{~mL} / \mathrm{min}$ targeted flowrate. Each test had 14 test runs. All effluent samples had no detected colonies, demonstrating that the filter does have the ability to remove a concentration of microorganisms at levels consistent with a loss of biocidal efficacy for a tank volume of $254 \mathrm{~L}$, the approximate volume of a $5 / 2$ service module and CM tank configuration.

The pressure drop from inlet to outlet averaged approximately 7 psid (Figure 9). Only the third test showed any increase in pressure drop across the filter as the test runs progressed; the other two tests showed periodic trends of increasing and decreasing pressure. The LabVIEW data acquisition application used to log the system pressure and the weight of the feed tank did not record the flowrate of the final two runs of test 3 . It is possible, therefore, that the run came close to reaching the maximum pressure drop allowed.

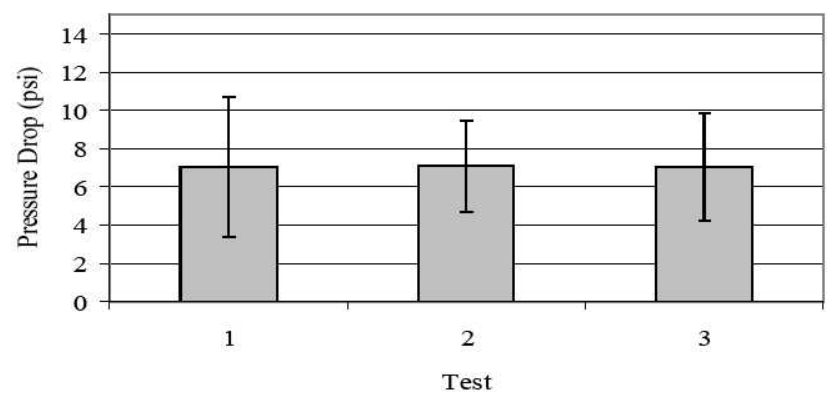

Figure 9. Pressure drop through filters during Part II

8

American Institute of Aeronautics and Astronautics 


\section{Potable Water System Processing Plan}

A PWS process plan was developed based on the results of the development plan work. To assure that the system can meet the long term water storage requirements, each of the major steps leading to the loading of the potable water in the tanks have to be carefully processed. The assembly process can be broken into three main section: contract end items (CEIs) such as the tanks and valve packages as provided by Hamilton Sundstrand (HS), the assembly of the CEIs with tubes into the vehicle, and the final loading of the potable water into the system.

The contract end items (CEIs), built by HS, will be cleaned and heat-treated in accordance with HS specifications for heat sterilization. This is the same process used in the past by HS for ISS potable water hardware. This process will ensure that all CEIs when delivered to KSC for assembly will start out clean and sterile prior to vehicle assembly. The titanium plumbing used in the vehicle will also be cleaned prior to assembly.

At assembly, welding will take place using a clean air purge, to minimize contamination into the system. After assembly into the vehicle, a high-concentration silver soak will be performed. This process will ensure all of the wetted area will be disinfected to a sufficient level, as well as help to surface-treat the titanium tubing and the Inconel ${ }^{\circledR}$ tank to increase the dwell time of silver in the finally loaded potable water.

After the PWS has been completely assembled and a high-concentration silver soak accomplished, loading of the potable water can occur. This water will be loaded to a level that is low in any TOC and through a $0.1-\mu$ microbial check filter. This ensures that the water loaded into the system is as clean as possible, as is the system itself. A sample of the water will be taken at the time of loading to insure that the loaded water remains clean and that the system is clean. A finale sample will be taken at a time after loading to insure that the water is still clean and that there wasn't any inadvertent contamination left in the system. If that sample results shows a major contamination issue, a remediation flush and reload of the system can then be performed.

\section{Conclusion}

The CEV water system employs a different strategy than any NASA has used in the past. The water must be stored for the long term with no continuous biocide addition, which entails depending a lot more on water system processing as the control. The premise is simple: If we start with a clean system and load it with clean water, the water within the system will remain clean. A POU filter is used both as a secondary control and to protect the clean system. Testing performed to date has shown that this approach is viable. While testing has been performed on individual components, an integrated system test of this approach will not be performed until vehicle qualification.

\section{Acknowledgments}

The authors of this paper would like to thank all the people that have provided inputs and testing results for the final process and verification process for Orion PWS. Big thanks to John Steele, Tony Rector, and Dogulas Snowdon at Hamilton Sundstrand for all their hard work and testing to help prove the concepts and alleviate concerns, and to LaShelle McCoy, Jay Garland, and Luke Roberson at KSC for their testing on the POU filter.

\section{References}

1"Crew Exploration Vehicle (CEV) Potable Water System Verification Coordination," ICES, 2008.

2“'Standard Test Method for Determining Bacterial Retention of Membrane Filters Utilized for Liquid Filtration," ASTM F838-05.

${ }^{3}$ Lingireddy, S., Ed. (2002). Control of Microorganisms in Drinking Water: A Report. Reston, ASCE.

\section{Acronyms}

$\begin{array}{ll}\text { AgF: } & \text { silver fluoride } \\ \text { ASTM: } & \text { American Society for Testing and Materials } \\ \text { CEI: } & \text { contract end item } \\ \text { CEV: } & \text { crew exploration vehicle } \\ \text { CFU: } & \text { colony-forming unit } \\ \mathrm{CO}_{2}: & \text { carbon dioxide } \\ \text { DI: } & \text { deionized } \\ \text { HS: } & \text { Hamilton Sundstrand } \\ \text { HSIR: } & \text { Human-Systems Integration Requirements } \\ \text { ISS: } & \text { International Space Station }\end{array}$




$\begin{array}{ll}\text { JSC: } & \text { Johnson Space Center } \\ \text { LCG: } & \text { liquid cooling garment } \\ \mathrm{Ni}_{2} \mathrm{O}: & \text { nickel oxide } \\ \mathrm{Ni}(\mathrm{OH})_{2}: & \text { nickel hydroxide } \\ \mathrm{NiCO}_{3}: & \text { nickel carbonate } \\ \text { P/N: } & \text { part number } \\ \text { POU: } & \text { point of use } \\ \text { ppm: } & \text { parts per million } \\ \text { psi: } & \text { pounds per square inch } \\ \text { psid: } & \text { pounds per square inch, differential } \\ \text { PWD: } & \text { potable water dispenser } \\ \text { PWS: } & \text { Potable Water System } \\ \text { Si/Nb: } & \text { silicon/niobium } \\ \text { SM: } & \text { service module } \\ \text { TOC: } & \text { total organic carbon } \\ \text { WMS: } & \text { Waste Management System } \\ \text { WPA: } & \text { water processing assembly }\end{array}$

